\title{
STANDARDIZATION OF DYNAMIC RX FOR PREOPERATIVE PLANNING IN ADOLESCENT IDIOPATHIC SCOLIOSIS
}

\author{
PADRONIZAÇÃO DO RX DINÂMICO PARA PLANEJAMENTO PRÉ-OPERATÓRIO NA ESCOLIOSE \\ IDIOPÁTICA DO ADOLESCENTE
}

\author{
NORMALIZACIÓN DE RX DINÁMICO PARA LA PLANIFICACIÓN PREOPERATORIA EN \\ ESCOLIOSIS IDIOPÁTICA DEL ADOLESCENTE
}

Everton Quadros Fiebig ${ }^{1}$, Carlos Henrioue Maçaneiro ${ }^{1}$, Ricardo Kiyoshi Miyamoto ${ }^{1}$, Rodrigo Fetter Lauffer ${ }^{1}$, Ricardo André Acácio dos Santos ${ }^{1}$

\begin{abstract}
Objective: To compare X-rays usually performed in supine with lateralization with those in lateral decubitus with fulcrum at the apex of the primary curve caused by cushion, in order to monitor the achievement of improvement patterns of correction in preestablished deformities for the preoperative surgical planning. Methods: Comparison of radiographic studies in the preoperative supine with lateralization and lateral decubitus with cushion performing fulcrum at the apex of the major curve in patients with adolescent idiopathic scoliosis. Results: Curves varied in AP between $76^{\circ}$ e $40^{\circ}$ and were corrected in supine with lateralization to the average of $21^{\circ}$ observing that when carried out with fulcrum with cushion in lateral decubitus the curves were corrected to $15^{\circ}$ on average with higher discrepancy in values among the most rigid curves. Conclusions: It was verified that on flexible curves the cushions did not produce satisfactory corrections in primary curves. In more rigid curves and in collaborative patients, greater effectiveness on the correction of deformity in main curves was obtained with cushions producing local fulcrum for a better preoperative planning on correction of deformities.
\end{abstract}

Keywords: Scoliosis; Adolescent; Radiography; Preoperative period.

RESUMO

Objetivo: Comparar os Raios-X $(R X)$ realizados usualmente em decúbito dorsal com lateralização com os realizados em decúbito lateral com fulcrum em ápice da curva primária provocado por coxim, a fim de verificar a obtenção de melhora dos padrões de correção das deformidades pre-estabelecidas para o planejamento cirúrgico pré-operatório. Métodos: Comparação de estudos radiográficos pré-operatórios em decúbito dorsal com lateralização e em decúbito lateral com coxim que produz fulcrum em ápice de curva principal de pacientes portadores de escoliose idiopática do adolescente. Resultados: As curvas variavam em projeção AP entre $76^{\circ}$ e $40^{\circ}$ e foram corrigidas em decúbito dorsal com lateralização para a média de $21^{\circ}$, obsenando-se que quando se empregou fulcrum com coxim em decúbito lateral, as curvas foram corrigidas em média para $15^{\circ}$, com maior discrepância de valores entre as curvas mais rígidas. Conclusões: Verificou-se que, em curvas flexíveis, os coxins não produziam correções exuberantes nas curvas primárias. Já nas curvas rígidas, e com pacientes colaborativos, obteve-se maior eficácia na correção da deformidade em sua curva principal, com os coxins produzindo fulcrum local para o melhor planejamento pré-operatório na correção das deformidades.

Descritores: Escoliose; Adolescente; Radiografia; Período pré-operatório.

\section{RESUMEN}

Objetivo: Comparar los RX realizados en general en decúbito dorsal con lateralización con los realizados en decúbito lateral con fulcro en el vértice de la curva primaria causado por cojines, con el fin de verificar la obtención de mejora de los patrones de corrección de las deformidades preestablecidas para la planificación quirúrgica preoperatoria. Métodos: Comparación de los estudios radiográficos en el preoperatorio en decúbito dorsal con lateralización y en decúbito lateral con cojines que produce fulcro de vértice de la curva principal de pacientes portadores de escoliosis idiopática adolescente. Resultados: Las curvas variaron en proyección $A P$ entre $76^{\circ}$ y $40^{\circ}$ y fueron corregidas en el decúbito dorsal con lateralización al promedio de $21^{\circ}$. También fue observado que cuando se emplea el fulcro con cojines en decúbito lateral, las curvas se corrigieron en promedio a $15^{\circ}$, con mayor discrepancia de valores entre las curvas más rígidas. Conclusiones: Se encontró que en curvas flexibles, los cojines no producían correcciones exuberantes en las curvas primarias. En curvas rígidas y con pacientes cooperativos se obtuvo una corrección más eficiente de la deformación en la curva principal, con los cojines produciendo fulcros locales para una mejor planificación preoperatorio para la corrección de las deformaciones.

Descriptores: Escoliosis; Adolescente; Radiografía; Periodo preoperatorio.

\section{INTRODUCTION}

Scoliosis is defined as a deviation of the coronal axis of the spine of more than 10 degrees, but it must be taken into account that this deformity is three-dimensional. The patient presents hypokyphosis in the sagittal plane, spinal rotation in the axial plane, and deviation from the midline in the coronal plane. ${ }^{1}$

According to its etiology it can be divided into: a) scoliosis secondary to neuromuscular alterations; b) congenital scoliosis; c) scoliosis secondary to syndromic diseases; and d) idiopathic scoliosis. ${ }^{1}$

Idiopathic scoliosis is prevalent in $80 \%$ of cases, and for this reason, it must be subdivided according to the appearance of signs of deformity correlated with the patient's age: I) infantile idiopathic scoliosis (from zero to three years of age), II) juvenile idiopathic scoliosis (older than three and up to ten years of age), III) adolescent idiopathic scoliosis (older than ten and up to eighteen years of age). ${ }^{2}$

1. Instituto de Ortopedia eTraumatologia de Joinville, Joinville, SC, Brazil. 
According to current research, the deformity is unique to humans. Its etiology is not well-known, but there are multiple factors involved in its genesis. Intrinsic factors, such as genetic factors, the growth and development of the spine, intervertebral discs, and longitudinal ligaments, and extrinsic factors, such as little understood neurological changes, deficiency in melanin production, functional alterations of the paravertebral musculature, and morphological changes of the platelets, among others, are involved in the spectrum of this pathology and there is much to be studied. ${ }^{3}$

Today, the norms recommended by the SRS (Scoliosis Research Society) and those studied by the Lenke group offer guidance for preoperative planning in adolescent idiopathic scoliosis (AIS). A radiographic study of the entire spine is necessary, with anteroposterior (AP) view, with profile $(P)$ view, and of the famous "bendings", which are films taken in dorsal decubitus with lateralization of the spine to correct primary and secondary curves, used to determine which area of the spine will undergo arthrodesis for correction of the deformity.

Our objective was to compare $\mathrm{x}$-rays normally taken in dorsal decubitus with lateralization with those taken in lateral decubitus with the fulcrum at the apex of the primary curve, using a cushion, to confirm whether an improvement has been obtained in the correction standards of pre-established deformities for preoperative surgical planning.

\section{METHODS}

Study evaluated by the Research Ethics Committee of the Hospital Regional Hans Dieter Schmidt, Joinville, SC, Brazil, with Registration no. 040/11.

The radiographic studies were conducted at the Department of Radiology of the Hospital Materno Infantil Jeser Amarante Faria (HJAF), Joinville, SC, Brazil, with patients with adolescent idiopathic scoliosis, aged between 10 and 18 years. Up until the present time, we have two boys and 14 girls registered in our database, with an average age of 13 years and 8 months, all of whom underwent surgery for correction of deformities.

All the procedures were accompanied by the patients' parents, who were informed about the study taking place and signed an informed consent form for the purposes of legal documentation and additional information. The exams were accompanied in full by the Orthopedic Doctor EQF.

The $x$-ray equipment available in the radiology unit of the HJAF was a VMI Pulsar Plus 500. Film plates of $35 \mathrm{~cm} \mathrm{X} 91 \mathrm{~cm}$ were used for the radiological development, in a cassette without diffuser grid. The standard techniques used were $30 \mathrm{MAS} / 60 \mathrm{KV}$ for the AP view and $45 \mathrm{MAS} / 70 \mathrm{KV}$ for the profile view. They were automatically developed in a Sigex processor. The patients filmed in lateral decubitus with a cushion were positioned at a focus-film distance of $120 \mathrm{~cm}$.

The custom-made cushions are semi-cylindrical with a $20 \mathrm{~cm}$ wooden base and a padded apex for the patient's comfort. They were in different sizes, for random selection based on the patient's BMl: $10 \mathrm{~cm}$ (BMI up to 20), $15 \mathrm{~cm}$ (BMl between 20 and 30), and $20 \mathrm{~cm}$ (BMl over 30). (Figures 1 to 7 ). Cushion number 1 was used 14 times and cushion number 2 was used twice.

All of the curves of the AP, dorsal decubitus with lateralization, and lateral decubitus with cushion were reviewed by an orthopedic evaluator, measured using the Cobb technique ${ }^{4}$ and based on the guidelines proposed by the Spinal Deformity Study Group. ${ }^{5}$

\section{RESULTS}

Two boys and 14 girls, with an average age of 13 years and 8 months, have been evaluated preoperatively to date, with $\mathrm{x}$-rays in AP/P, dorsal decubitus with lateralization to the right and left, and lateral decubitus with fulcrum at the apex of the main curve.

The curves (ranging between $76^{\circ}$ and $40^{\circ}$ ) in the AP view were corrected in the dorsal decubitus with lateralization by an average

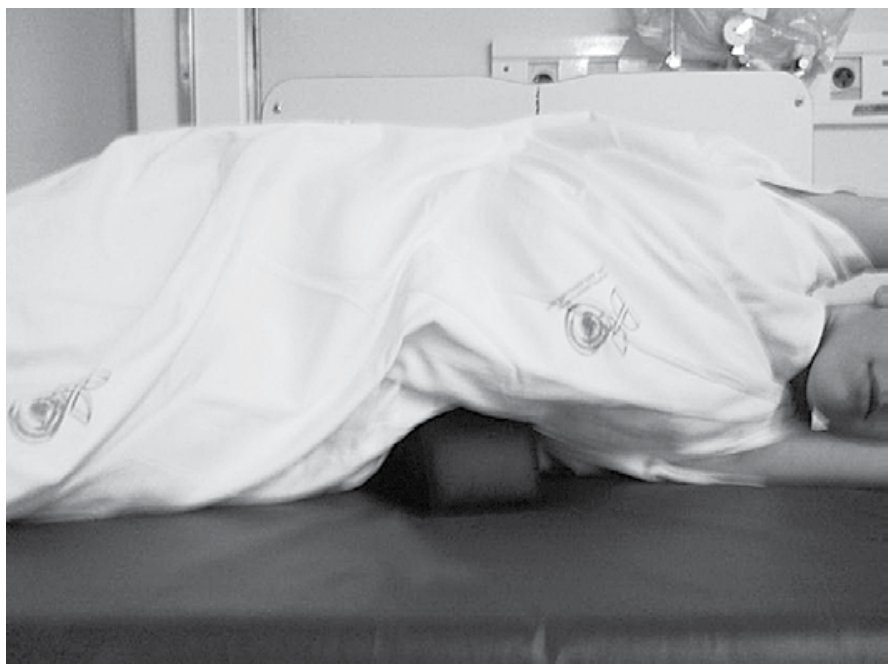

Figure 1. Positioning of the patient on the cushion.

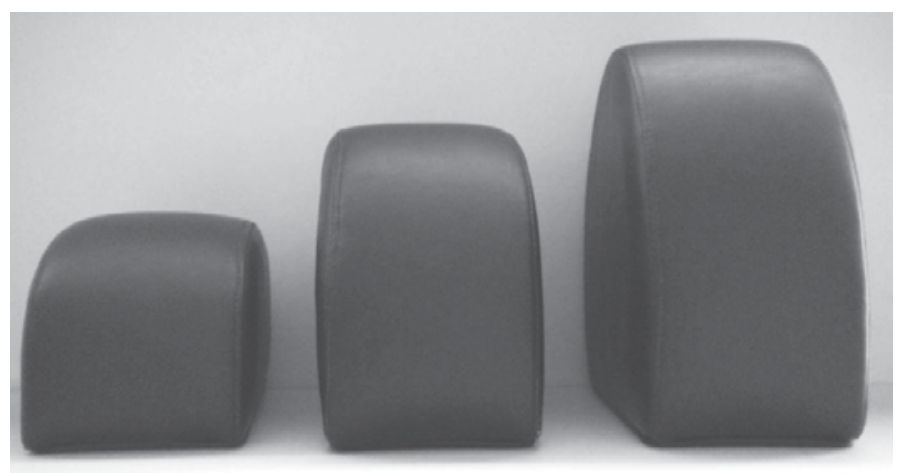

Figure 2. Cushions used to create the fulcrum; view ofthe base.

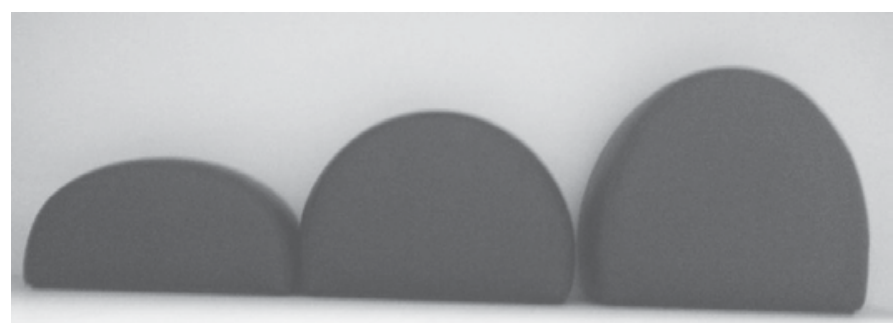

Figure 3. View of the height of the cushions.

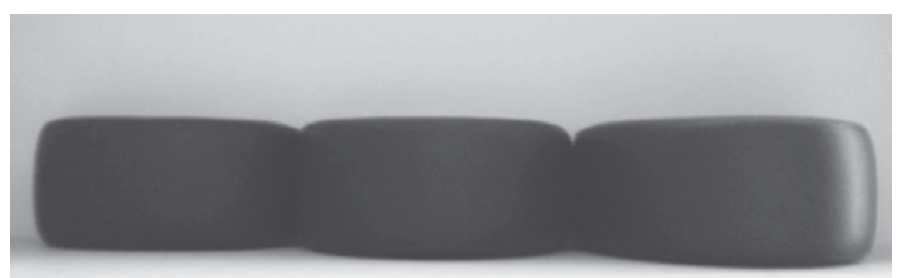

Figure 4. View of the apex of the cushions.

of $21^{\circ}$, and it was observed that when a fulcrum was created using a cushion in lateral decubitus, the curves were corrected by an average of $15^{\circ}$, as shown in Table 1.

\section{DISCUSSION}

In the literature review conducted, it was observed that, according to the SRS, three techniques can be performed: A) x-ray with the patient in dorsal decubitus on a table tilted to the right and then to the left; B) films taken with the patient's arms and legs in traction to stretch the spine, causing correction of the curve; or $\mathrm{C}$ ) 


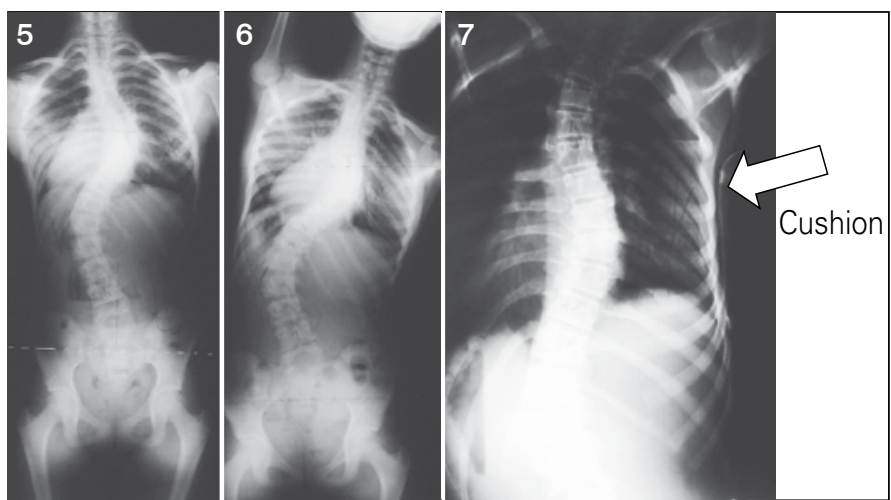

Figures 5, 6 and 7. X-ray in AP, free lateral decubitus (FLD), lateral decubitus with cushion (LDC).

Table 1. Comparison between free lateral decubitus (FLD) X lateral decubitus with cushion (LDC) x-rays.

\begin{tabular}{c|c|c|c|c|c}
\hline Patient & Age & Sex & AP & FLD & LDC \\
\hline 1 & $12+7$ & $\mathrm{~F}$ & $\mathrm{~T} 6 / \mathrm{T} 12-76^{\circ}$ & $49^{\circ}$ & $45^{\circ}$ \\
\hline 2 & $16+7$ & $\mathrm{~F}$ & $\mathrm{~T} 6 / \mathrm{L} 1-40^{\circ}$ & $3^{\circ}$ & $2^{\circ}$ \\
\hline 3 & $12+9$ & $\mathrm{~F}$ & $\mathrm{~T} 8 / \mathrm{L} 4-43^{\circ}$ & $10^{\circ}$ & $10^{\circ}$ \\
\hline 4 & $12+1$ & $\mathrm{~F}$ & $\mathrm{~T} 6 / \mathrm{T} 11-53^{\circ}$ & $40^{\circ}$ & $16^{\circ}$ \\
\hline 5 & $11+2$ & $\mathrm{M}$ & $\mathrm{T} 5 / \mathrm{T} 12-40^{\circ}$ & $2^{\circ}$ & $2^{\circ}$ \\
\hline 6 & $12+3$ & $\mathrm{~F}$ & $\mathrm{~T} 5 / \mathrm{T} 12-71^{\circ}$ & $31^{\circ}$ & $29^{\circ}$ \\
\hline 7 & $12+8$ & $\mathrm{~F}$ & $\mathrm{~T} 10 / \mathrm{L} 3-46^{\circ}$ & $8^{\circ}$ & $4^{\circ}$ \\
\hline 8 & 14 & $\mathrm{~F}$ & $\mathrm{~T} 11 / \mathrm{L} 3-45^{\circ}$ & $6^{\circ}$ & $3^{\circ}$ \\
\hline 9 & $14+1$ & $\mathrm{~F}$ & $\mathrm{~T} 5 / \mathrm{T} 12-52^{\circ}$ & $12^{\circ}$ & $11^{\circ}$ \\
\hline 10 & 16 & $\mathrm{~F}$ & $\mathrm{~T} 10 / \mathrm{L} 3-65^{\circ}$ & $38^{\circ}$ & $25^{\circ}$ \\
\hline 11 & $14+9$ & $\mathrm{~F}$ & $\mathrm{~T} 5 / \mathrm{T} 12-48^{\circ}$ & $27^{\circ}$ & $20^{\circ}$ \\
\hline 12 & $17+8$ & $\mathrm{~F}$ & $\mathrm{~T} 6 / \mathrm{L} 3-66^{\circ}$ & $46^{\circ}$ & $40^{\circ}$ \\
\hline 13 & $17+11$ & $\mathrm{~F}$ & $\mathrm{~T} 11 / \mathrm{L} 3-40^{\circ}$ & $4^{\circ}$ & $4^{\circ}$ \\
\hline 14 & $14+7$ & $\mathrm{~F}$ & $\mathrm{~T} 12 / \mathrm{L} 4-42^{\circ}$ & $18^{\circ}$ & $10^{\circ}$ \\
\hline 15 & $14+6$ & $\mathrm{~F}$ & $\mathrm{~T} 7 / \mathrm{L} 1-42^{\circ}$ & $8^{\circ}$ & $3^{\circ}$ \\
\hline 16 & 13 & $\mathrm{M}$ & $\mathrm{T} 5 / \mathrm{T} 12-65^{\circ}$ & $48^{\circ}$ & $20^{\circ}$ \\
\hline
\end{tabular}

fulcrum bending radiography with a padded roll positioned at the apex of the curve to correct the deformity. ${ }^{2}$

The studies conducted by Lenke et $\mathrm{al}^{6}$ suggest the use of bendings in the supine position, the same routine as that adopted by King et $\mathrm{al}^{7}$ in their classic study on the selection of the arthrodesis site in thoracic scoliosis and other works., ${ }^{8,9,10}$

In the authors' clinical practice, it was observed that performing lateralization exams with the patient standing, or with the patient in dorsal decubitus on a table without stabilization of the pelvis, inter- feres in the correct evaluation of the correction of scoliotic curves. The creation of cushions to create the fulcrum was discussed, and we observed that, in flexible curves, where the dorsal decubitus with lateralization is less than $25^{\circ}$, the corrections achieved with the cushion were similar to those achieved using only dorsal decubitus with lateralization. The corrections of rigid curves and in cooperative patients were more evident, and depended on individual tolerance, because the fulcrum at the apex of the scoliotic curve causes local pain. There were no neurological repercussions during or following the exam, as shown in the table.

There is a lack of information in the literature related to preoperative planning for patients with AIS in relation to bendings. In 2005, a group of orthopedists in Nottingham/UK published a study that minimized the action of the patient, conducting traction exams under anesthesia at the surgery center to correct the scoliotic curve and achieving an average correction value of $30^{\circ}$, as compared to those conducted in dorsal decubitus with lateralization, which achieved an average of $47^{\circ}$. The average correction of the curves in $\mathrm{AP}$ was $69^{\circ}$. A better correlation was obtained between the radiographic study performed under anesthesia and the postoperative levels achieved following correction of the deformity. ${ }^{11}$

An important factor observed during the study was that the cushion with the $10 \mathrm{~cm}$ apex was sometimes inadequate to support just the apex of the main curve, generating less extensive corrections than would have been expected if it had been possible to isolate this region without causing such discomfort as to prevent the completion of the exam.

This experimental study will be revised and improved so that the methodology might be adapted for the radiographic study of non-collaborative patients, such as those with cerebral palsy or syndromic diseases, in order to carry out preoperative planning that is more in keeping with the surgical procedure to be performed, with the scheduling of multiple osteotomies if required.

\section{CONCLUSIONS}

It was obvious to the group how adequate preoperative planning enables transoperative reproduction of what was planned, without major complications. The study effectively demonstrated that the fulcrum created by the cushion in rigid curves presented better correction than $\mathrm{x}$-rays performed in dorsal decubitus with lateralization. But it is clear that there is a lack of literature comparing preoperative techniques of bending radiography. This work therefore provides a model for possible reproduction in spinal surgery training services accredited by the Brazilian Society of Spinal Surgery (SBC) that perform surgeries for the correction of scoliosis/deformities.

All authors declare no potential conflict of interest concerning this article.

\section{REFERENCES}

1. Newton PO, Wenger DR. Idiopathic Scoliosis. In: Morrissy RT, Weinstein SL,editors. Lovell \&Winter's pediatric orthopaedics. 6th ed. Philadelphia: Lippicott Williams; 1998. p. 694-792.

2. Scoliosis Research Society. Adolescent Idiopathic Scoliosis. [citado em 31 de março de 2009]. Disponivel em: www.srs.org/professionals/education/adolescent/idiopathic.

3. Kouwenhoven JW, Castelein RM. The pathogenesis of adolescent idiopathic scoliosis: review of the literature. Spine (Phila Pa 1976). 2008;33(26):2898-908.

4. Cobb JR. Outline for the study of scoliosis. Instr Course Lect AAOS. 1948:5:261-75.

5. O'Brien MF, Kuklo TR, Blanke KM, Lenke LG, editors. Spinal deformity study group radiographic measurement manual. Minneapolis: Medtronic Sofamor Danek, Inc; 2005.

6. Lenke LG, Betz RR, Harms J, Bridwell KH, Clements DH, Lowe TG, Blanke K. Adolescent idiopathic scoliosis: a new classification to determine extent of spinal arthrodesis. J Bone Joint Surg Am. 2001;83(8):1169-81.
7. King HA, Moe JH, Bradford DS, Winter RB. The selection of fusion levels in thoracic idiopathic scoliosis. J Bone Joint Surg Am. 1983;65(9):1302-13.

8. Herkowitz HN, Garfin SR, Einsmont FJ, Bell GR, Balderston RA. Rothman-Simeone: the spine. 6th ed. New York: Saunders Elsevier; 2011. p. 385-401.

9. Canale ST, Beaty JH. Campbell's operative orthopaedics. 10th ed. Philadelphia: Elsevier; 2033. p. 1752-872

10. Erickson MA, Baulesh DM. Lowest instrumented vertebra selection in AIS. J Pediatr Orthop. 2011;31(Suppl 1):S69-76.

11. El-Abed K, Ali S, Dixon S, Hutchinson MJ, Nelson IW. Prediction of surgical correction of idiopathic scoliosis: A comparison of fulcrum bending and traction radiographs. J Bone Joint Surg Br. 2005:87(Suppl 3):237. 